\title{
Liability and Compensation for Activities in the Area
}

\author{
Kristoffer Svendsen
}

\section{1 \\ Introduction}

All States have a duty to prevent harm to the environment including the marine environment. States also have '... the responsibility to ensure that activities within their jurisdiction or control do not cause damage to the environment of other States or of areas beyond the limits of national jurisdiction.' ${ }^{1}$ Similar language is found in the United Nations Convention on the Law of the Sea (UNCLOS), which provides that 'States have the obligation to protect and preserve the marine environment.' ${ }^{2}$ UNCLOS sets forth a governance and enforcement system of our global ocean where part of the ocean is under national jurisdiction and sovereignty, after which the remaining part of the ocean is located beyond national jurisdiction (the Area), in which the freedom of the high seas applies. ${ }^{3}$ No State has sovereignty or sovereign rights to the Area, and the Area's minerals can only be extracted according to Part XI in the UNCLOS. The International Seabed Authority (ISA) was created to organise, control, and carry out exploration exploitation activities in the Area. ${ }^{4}$ The ISA has thereafter developed, and continues to develop, the 'Mining Code', which is a '... comprehensive set of rules, regulations and procedures issued by the International Seabed Authority to regulate prospecting, exploration and exploitation of marine minerals in the international seabed Area (defined as the seabed and subsoil beyond the limits of national jurisdiction). ${ }^{5}$ The current three key regulations of the 'Mining Code' are IsA Regulations on Prospecting

1 Declaration of the United Nations Conference on the Human Environment, 5-16 June 1972, Stockholm, Art. 21.

2 UNCLOS Art. 192.

3 See UnClos Part XI and Art. 87.

4 Id. at. Art. 153.

5 ISA, 'The Mining Code' at <https://www.isa.org.jm/mining-code $>$. 
and Exploration for Polymetallic Nodules, ${ }^{6}$ Polymetallic Sulphides, ${ }^{7}$ and Cobalt-Rich Crusts, ${ }^{8}$ in the Area.

The interest in exploration and exploitation of seabed minerals has increased. The ISA has in total entered into 15-year contracts for exploration for polymetallic nodules, polymetallic sulphides and cobalt-rich ferromanganese crusts in the deep seabed with 29 contractors. ${ }^{9} 17$ of these 29 contracts are for exploration for polymetallic nodules: 16 contracts in the Clarion-Clipperton Fracture Zone, which is a geological submarine fracture zone of the Pacific Ocean, and one contract in the Central Indian Ocean Basin..$^{10}$ There are seven contracts for exploration for polymetallic sulphides in the South West Indian Ridge, Central Indian Ridge and the Mid-Atlantic Ridge and five contracts for exploration for cobalt-rich crusts in the Western Pacific Ocean. ${ }^{11}$ These contracts grant the contractors the exclusive right to explore an initial area of up to 150,000 square kilometres of specified parts of the deep oceans outside national jurisdiction. ${ }^{12}$

As a result of the transition of deep seabed mining in the Area from the exploration phase to the exploitation phase, the Legal and Technical Commission of the ISA started working on drafting regulations and standard contract terms on exploitation for mineral resources in the Area in $2015 .{ }^{13}$ The draft exploitation regulations are currently under development. The first draft was published in July 2016 and were still under discussion at the time of the 25 th Annual Session

International Seabed Authority Council, Decision of the Council of the International Seabed Authority relating to amendments to the Regulations on Prospecting and Exploration for Polymetallic Nodules in the Area and related matters, ISBA/19/C/17, 22 July 2013, at <https://www.isa.org.jm/documents/isbargc17>.

7 International Seabed Authority Assembly, Regulations on prospecting and exploration for polymetallic sulphides in the Area, ISBA/16/A/12/Rev.1, 7 May 2010, at <https://www .isa.org.jm/documents/isba16a12-rev-1>.

8 International Seabed Authority Assembly, Regulations on Prospecting and Exploration for Cobalt-rich Ferromanganese Crusts in the Area, ISBA/18/A/11, 27 July 2012, at $<$ https://www.isa.org.jm/documents/isba18a11>.

9 ISA, 'Deep Seabed Minerals Contractors' at <https://www.isa.org.jm/deep-seabed-mine rals-contractors $>$.

10 Ibid.

11 Ibid.

12 See above $\mathrm{n}$ 6. Reg. 24.1 and 25.1. For a complete review of the applicable general regime, see J. Dingwall, Chapter 7 of this book, 'Commercial Mining Activities in the Deep Seabed Beyond National Jurisdiction: The International Legal Framework.'

13 The Legal and Technical Commission of the International Seabed Authority (2016) Working Draft Regulations and Standard Contract Terms on Exploitation for Mineral Resources in the Area at https://www.isa.org.jm/files/documents/EN/Regs/DraftExpl/ Draft_ExplReg_SCT.pdf. 
of ISA in July 2019. In principle, the draft exploitation regulations should be finalised by 2020.

The current draft regulations contain sections on: form of applications; fee for applications; processing of applications; consideration of applications by the Commission and Council; exploitation contracts; plan of work for exploitation; annual fees; royalties; returns, payments and refunds; record, inspection and audit; anti-avoidance measures; interests and penalties; suspension or termination of contract; disputes and review of payments; information gathering and handling; inspections; enforcement and penalties; dispute settlement; and review of the Authority's regulations. The draft regulations however do not construct a model for liability and compensation for damage as a result of these activities.

The current chapter is a contribution to the discussion on how to compensate damage caused by activities in the Area. The chapter sketches the current parallel system of the sponsoring State's responsibility for damage caused in the Area and the sponsored contractor's liability for damage caused in the Area (Section 2). The chapter attempts to draw a model for an improved liability and compensation system for damage caused by deep-sea mining in the Area (Section 3). The chapter ends with some concluding remarks (Section 4).

\section{The Current 'System' of Responsibility and Liability for Pollution Damage Caused in the Area}

\subsection{Prelude}

To ensure compensation of environmental damage, UNCLOS places responsibility on the sponsoring State of the company applying for exploration and exploitation in the Area to ensure compliance with the applicable parts of UNCLOS, a breach of which places liability on the supporting State. ${ }^{14}$ The International Tribunal for the Law of the Sea (ITLOS) gave an Advisory Opinion 1 February 2011 on the Responsibilities and Obligations of States Sponsoring Persons and Entities with Respect to Activities in the Area ${ }^{15}$ based on Nauru's submission of an application for approval of a work plan for exploratory seabed mining activities to the ISA, 'but had become concerned that the potential

\footnotetext{
14 See UNCLOS Part XI and art. 139.

15 ITLOS, Advisory Opinion of 1 February 2011, Responsibilities and Obligations of States Sponsoring Persons and Entities with Respect to Activities in the Area, at $<\mathrm{https}$ ://www .itlos.org/fileadmin/itlos/documents/cases/case_no_17/17_adv_op_010211_en.pdf >.
} 
liabilities or costs arising from its sponsorship of a mining entity might exceed its financial capacities as a developing country.'16

\subsection{Sponsorship}

The notion of sponsorship is a key element in the exploration and exploitation system of resources in the Area. ${ }^{17}$ Enterprises and, in association with the Authority, States Parties, or state enterprises or natural or juridical persons can engage in activities in the Area. ${ }^{18}$ Natural and juridical persons must however satisfy two requirements to be eligible to engage in activities in the Area: 1) 'they must be either nationals of a State Party or effectively controlled by it or its nationals, ${ }^{19}$ and 2) 'they must be "sponsored by such States". 20 The requirement of sponsorship similarly identically applies to state enterprises. ${ }^{21}$ States Parties themselves engaged in deep seabed mining are directly bound by the obligations set forth in UNCLOS and does not need sponsorship. ${ }^{22}$

The sponsorship requirement is crucial, creating the necessary nexus between the international legal treaty only binding on the States Parties and the domestic legal systems, of which the Enterprises are subjects. ${ }^{23}$ The nexus between States Parties and subjects of domestic law consists of the nationality and effective control, which requires all contractors and applicants for contracts to 'secure and maintain the sponsorship of the State or States of which they are nationals. If another State or its nationals exercises effective control, the sponsorship of that State is also necessary.'24 All sponsoring States are in such situations jointly and severally liable, unless otherwise provided in ISA regulations. ${ }^{25}$

16 Gunther Handl, 'Responsibilities and Obligations of States Sponsoring Persons and Entities with respect to Activities in the Area: the International Tribunal of the Law of the Sea's recent Contribution to International Environmental Law (2011) Review of European Community \& International Environmental Law, 20, pp. 208-213.

17 ITLOS, Advisory Opinion of 1 February 2011, supra note 15 at p. 32.

18 UNCLOS Art. 1532.

19 ITLOS, Advisory Opinion of 1 February 2011, supra note 15 at p. 32 and UnCLOS Art. 153 $2(\mathrm{~b})$.

20 Ibid.

21 Ibid.

22 Id at p. 33, UnCLOS Art. 153 2(b), and Annex III Art. 45.

23 ITLOS, Advisory Opinion of 1 February 2011, supra note 15 at p. 33.

24 Id at p. 33 and UnClos Annex III Art. 43.

25 Id at p. 62 . 


\subsection{Liability in General}

In its advisory opinion, the Tribunal sets forth the system and different sources of liability as stated in UNCLOS:

1) rules concerning the liability of State Parties (article 139, paragraph 2, first sentence), ${ }^{26}$

2) rules concerning sponsoring State liability (article 139, paragraph 2, second sentence), ${ }^{27}$ and

3) rules concerning the liability of the contractor and the Authority (referred to in Annex III, article 22).

Paragraph 2 of article 139 attach liability on a sponsoring State from its failure to carry out its own responsibilities, while not being liable for the failure of the sponsored contractor to meet its obligations. 'There is, however, a link between the liability of the sponsoring State and the failure of the sponsored contractor to comply with its obligations, thereby causing damage. 28 This chapter discusses these rules more in-depth and towards the end offers some suggestions on improvements.

\subsection{State Fault-Based Responsibility for Failure to Properly Perform Due Diligence - Secondary Fault-Based Liability}

The State(s) sponsoring contractors or applicants for contracts for the exploration and exploitation of resources in the Area have responsibilities and obligations under the UNCLOS. These obligations are characterised as 'direct obligations.' ${ }^{29}$ The main direct obligations incumbent on the sponsoring States are:

the obligation to assist the Authority in the exercise of control over activities in the Area; the obligation to apply a precautionary approach; the obligation to apply best environmental practices; the obligation to take measures to ensure the provision of guarantees in the event of an emergency order by the Authority for protection of the marine environment;

26 First sentence states: 'Without prejudice to the rules of international law and Annex III, article 22, damage caused by the failure of a State Party or international organization to carry out its responsibilities under this Part shall entail liability; States Parties or international organizations acting together shall bear joint and several liability.'

27 Second sentence states: 'A State Party shall not however be liable for damage caused by any failure to comply with this Part by a person whom it has sponsored under article 153, paragraph 2(b), if the State Party has taken all necessary and appropriate measures to secure effective compliance under article 153, paragraph 4, and Annex III, article 4, paragraph 4.'

28 ITLOS, Advisory Opinion of 1 February 2011, supra note 15 at p. 57.

29 Id at p. 44. 
the obligation to ensure the availability of recourse for compensation in respect of damage caused by pollution; and the obligation to conduct environmental impact assessments. ${ }^{30}$

The sponsoring State's liability for failure to meet its direct obligations is governed exclusively by the first sentence of paragraph 2 of article 139, while a sponsoring State's liability for a failure to meet its obligations in relation to damage caused by a sponsored contractor is covered by both the first and second sentences of article $139 .{ }^{31}$ The nature of these obligations obviously does define and determine the scope of liability.

In its advisory opinion ITLOS relied on UNCLOS article 139 paragraph $1,{ }^{32}$ article 153 paragraph $4,{ }^{33}$ and Annex III article 4 paragraph $4,{ }^{34}$ when confirming that "the obligation (responsibility) of the sponsoring State is "to ensure" that the "activities in the Area" conducted by the sponsored contractor are "in conformity" or in "compliance" with the rules to which they refer. 35 The Tribunal highlighted that one of the sponsoring State's obligations under international law expressed as a 'responsibility to ensure' in UNCLOS establishes a mechanism where UNCLOS rules concerning activities in the Area become

$30 \quad$ Ibid.

$31 \quad$ Id at p. 58 .

32 The paragraph states: 'States Parties shall have the responsibility to ensure that activities in the Area, whether carried out by States Parties, or state enterprises or natural or juridical persons which possess the nationality of States Parties or are effectively controlled by them or their nationals, shall be carried out in conformity with this Part. The same responsibility applies to international organizations for activities in the Area carried out by such organizations.'

33 The paragraph states: 'The Authority shall exercise such control over activities in the Area as is necessary for the purpose of securing compliance with the relevant provisions of this Part and the Annexes relating thereto, and the rules, regulations and procedures of the Authority, and the plans of work approved in accordance with paragraph 3. States Parties shall assist the Authority by taking all measures necessary to ensure such compliance in accordance with article 139.'

34 The paragraph states: 'The sponsoring State or States shall, pursuant to article 139, have the responsibility to ensure, within their legal systems, that a contractor so sponsored shall carry out activities in the Area in conformity with the terms of its contract and its obligations under this Convention. A sponsoring State shall not, however, be liable for damage caused by any failure of a contractor sponsored by it to comply with its obligations if that State Party has adopted laws and regulations and taken administrative measures which are, within the framework of its legal system, reasonably appropriate for securing compliance by persons under its jurisdiction.'

ITLOS, Advisory Opinion of 1 February 2011, supra note 15 at p. 40. 
effective for sponsored contractors, which are bound by domestic law and not UNCLOS perse. ${ }^{36}$

A violation by the sponsoring state of this obligation 'to ensure' entails liability for the actual amount of damage. ${ }^{37}$ The sponsoring State remains liable for damage also after the completion of the exploration phase. ${ }^{38}$ Paragraph 2 of article 139 requires two conditions for liability to arise: 1) the failure of the sponsoring State to carry out its responsibilities and 2) the occurrence of damage. ${ }^{39}$ Such failure may be 'act or an omission that is contrary to that State's responsibilities under the deep seabed mining regime. ${ }^{\prime 0}$ That said, a sponsoring State is only liable for a failure to carry out its responsibilities when damage has been inflicted. Thus, no matter the situation, no damage equals no liability for the sponsoring State. ${ }^{41}$ Therefore, 'in order for the sponsoring State's liability to arise, there must be a causal link between the failure of that State and the damage caused by the sponsored contractor. ${ }^{2} 2$ This causal link cannot be presumed and must be proven. ${ }^{43}$ Strict liability is therefore not the standard of liability for a sponsoring state. ${ }^{44}$

'However, not every violation of an obligation by a sponsored contractor automatically gives rise to the liability of the sponsoring State. Such liability is limited to the State's failure to meet its obligation to "ensure" compliance by the sponsored contractor. ${ }^{45}$ As such, a private entity's failure does not trigger liability for the sponsoring State, but is a mere trigger mechanism for

$36 \quad$ Id at p. 41 .

37 UNCLOS Art. 139, paragraph 2, first sentence and ITLOS, Advisory Opinion of 1 February 2011, supra note 15 at p. 62.

38 ITLOS, Advisory Opinion of 1 February 2011, supra note 15 at p. 63.

$39 \quad$ Id at. p. 58.

40 Ibid.

41 This is an exception from the customary international law rule on liability where 'a State may be held liable under customary international law even if no material damage results from its failure to meet its international obligations.' ITLOS, Advisory Opinion of 1 February 2011, supra note 15 at p. 58, relying on Rainbow Warrior Arbitration at paragraph 110 (Case concerning the difference between New Zealand and France concerning the interpretation or application of two agreements, concluded on 9 July 1986 between the two States and which related to the problems arising from the Rainbow Warrior Affair, UNRIAA, 1990, vol. xx, p. 215) and paragraph 9 of the Commentary to article 2 of the International Law Commission 'Draft articles on Responsibility of States for Internationally Wrongful Acts, with commentaries' (2001) II Yearbook of the International Law Commission, Part Two.

42 ITLOS, Advisory Opinion of 1 February 2011, supra note 15 at p. 59.

43 Id at p. 60.

$44 \quad$ Id at p. 61.

45 Id at p. 41. 
potentially giving rise to liability. Only the sponsoring State's own failure to carry out its own responsibilities give rise to liability for the sponsoring State. ${ }^{46}$ The Tribunal importantly pointed out that:

The sponsoring State's obligation "to ensure" is not an obligation to achieve, in each and every case, the result that the sponsored contractor complies with the aforementioned obligations. Rather, it is an obligation to deploy adequate means, to exercise best possible efforts, to do the utmost, to obtain this result. To utilize the terminology current in international law, this obligation may be characterized as an obligation "of conduct" and not "of result", and as an obligation of "due diligence". 47

In explaining the obligation to act with due diligence, the Tribunal quoted the International Court of Justice in Pulp Mills on the River Uruguay (Argentinav. Uruguay):

It is an obligation which entails not only the adoption of appropriate rules and measures, but also a certain level of vigilance in their enforcement and the exercise of administrative control applicable to public and private operators, such as the monitoring of activities undertaken by such operators ... ${ }^{48}$

The International Law Commission expressed the same view. ${ }^{49}$ Thus, the Tribunal confirmed that sponsoring States are only liable for a failure to not properly perform their due diligence. The content of this due diligence obligation is not precise partly due to diligence as 'a variable concept'. ${ }^{50}$ Sufficiently diligent measures can be insufficient with time as a result of for example 'new scientific or technological knowledge. 51 The level of due diligence also increases according to the level of risk. The Tribunal stated that 'the standard of due diligence has to be more severe for the riskier activities. 52 The sponsoring

$46 \quad$ Id at p. 60.

47 Id at p. 41.

48 Pulp Mills on the River Uruguay (Argentina v. Uruguay), Judgment, I.C.J. Reports 2010, p. 14, paragraph 197.

49 ITLOS, Advisory Opinion of 1 February 2011, supra note 15 at p. 42 quoting the Prevention of Transboundary Harm from Hazardous Activities, 2001, Official Records of the General Assembly, Fifty-sixth Session, Supplement No. 10 (A/56/10).

50 ITLOS, Advisory Opinion of 1 February 2011, supra note 15 at p. 43.

$51 \quad$ Ibid.

52 Ibid. 
State must adopt within its legal system 'reasonably appropriate' measures to comply with the standard of due diligence appropriate to the level of risk, for which the measures are adopted. ${ }^{53}$ Compliance with the above-listed direct obligations 'can also be seen as a relevant factor in meeting the due diligence "obligation to ensure" and that the said obligations are in most cases couched as obligations to ensure compliance with a specific rule. 54

Sponsoring States also have another direct obligation, which 'gives substance to the sponsoring State's obligation to adopt laws and regulations within the framework of its legal system. ${ }^{55}$ Article 235, paragraph 2, states as follows:

States shall ensure that recourse is available in accordance with their legal systems for prompt and adequate compensation or other relief in respect of damage caused by pollution of the marine environment by natural or juridical persons under their jurisdiction.

Article 235, paragraph 2, applies to sponsoring States as 'the State with jurisdiction over the persons that caused the damage. ${ }^{56}$ The Tribunal also points out that States may also need to 'establish substantive rules governing claims for damages before its domestic courts ... ensuring that the sponsored contractor meets its obligation under Annex III, article 22, of the Convention to provide reparation for damages caused by wrongful acts committed in the course of its activities in the Area. ${ }^{57}$ Additionally, the sponsoring State's laws, regulations, and administrative measures must be in force during the whole period of the contract between ISA and the contractor. ${ }^{58}$ The existence of such laws, regulations, and administrative measures are not a condition precedent for concluding a contract with ISA, but it is a necessary requirement for compliance with the obligation of due diligence of the sponsoring State and for its exemption from liability.59 If ISA regulations are passed after already existing sponsoring State legislation, sponsoring States are under an obligation to make the necessary amendments to such legislation to keep with the provisions of

\begin{tabular}{ll}
\hline 53 & Ibid. \\
54 & Id at p. 44. \\
55 & Id at p. 49. \\
56 & Ibid. \\
57 & Ibid. \\
58 & Id at p. 68. \\
59 & Ibid.
\end{tabular}


the ISA regulations. ${ }^{60}$ Importantly, State laws, regulations, and administrative measures cannot be in perpetuity. ${ }^{61}$

Examples of domestic law rules are provisions concerning 'financial viability and technical capacity of sponsored contractors, conditions for issuing a certificate of sponsorship and penalties for non-compliance by such contractors, ${ }^{6} 2$ and enforcement mechanisms of ITLOS decisions. Example of administrative measures are 'the establishment of enforcement mechanisms for active supervision of the activities of the sponsored contractor, ${ }^{63}$ and to coordinate better efficiency between the sponsored contractor and ISA to remove activities leading to duplicate work. ${ }^{64}$

If the sponsoring State has taken the 'reasonably appropriate' measures and thus complied with its due diligence standard under the UNLOS, the sponsoring State is exempt from liability for damage inflicted by the sponsored contractor. $^{65}$ This can result in situations, in which a sponsoring State has fulfilled its due diligence standard, while, at the same time, damage has been inflicted in the Area and has not been compensated. The question becomes on whom to place liability for harm inflicted beyond national jurisdiction without any fault by a sponsoring State in exercising its obligation to prevent harm because the standard of care required is met? The Tribunal and the UNCLOS are clear on the fact that liability cannot be placed on the sponsoring State in such a situation.

\subsection{Simultaneous Contractor Liability for Pollution Damage - National Legislation}

UNCLOS requires a contractor that wants to engage in deep seabed mining to first secure and thereafter maintain the sponsorship of a State, as mentioned above. Sponsorship is the mechanism for domestic legal entities to comply with the international legal obligations of UNCLOS only binding on State Parties, and ISA's regulations and instruments applicable to these domestic legal entities. ${ }^{66}$ As stated in Annex III, article 4, paragraph 4:

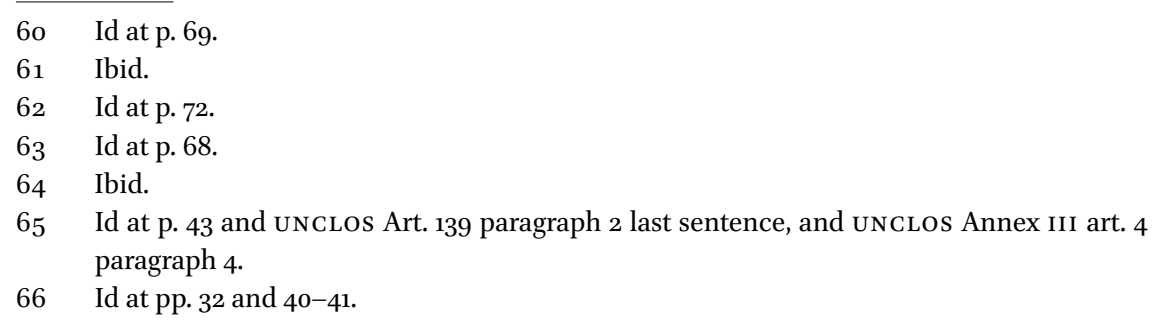


The sponsoring State or States shall, pursuant to article 139, have the responsibility to ensure, within their legal systems, that a contractor so sponsored shall carry out activities in the Area in conformity with the terms of its contract and its obligations under this Convention. A sponsoring State shall not, however, be liable for damage caused by any failure of a contractor sponsored by it to comply with its obligations if that State Party has adopted laws and regulations and taken administrative measures which are, within the framework of its legal system, reasonably appropriate for securing compliance by persons under its jurisdiction.

A sponsoring State is obligated to adopt laws and regulations and to take the administrative measures necessary, as the contractor's obligations cannot all be enforced through administrative measures and contractual arrangements. ${ }^{67}$ This is partly because contractual obligations cannot be invoked by other entities, than the parties to the contract, against the sponsoring State, and that contracts generally lacks transparency as it is difficult for the public to measure the sponsoring State's success in meeting its requirements. ${ }^{68}$ Annex III of UNCLOS and ISA regulations do not require a sponsorship agreement between the contractor and the sponsoring State, nor its submission to ISA or public publication if in existence. ${ }^{69}$ The sponsoring State is only required to submit a certificate of sponsorship to ISA stating its assumption responsibility according to article 139, article 153, paragraph 4, and Annex III, article 4, paragraph 4, of UNCLOS. ${ }^{70}$

That said, the sponsored contractor is obviously obligated to conduct its activities in the Area according to the terms of the contract. Even though 29 contracts have been entered into, ISA's Legal and Technical Commission are now developing standard contractual terms 'on exploitation for Mineral Resources in the Area for consideration by the Members of the Authority and all stakeholders. ${ }^{71}$ If a sponsored contractor fails to comply with rules in UNCLOS, in the ISA seabed-mining regime, or in the contract, which results in damage the sponsoring State is not liable. ${ }^{72}$

\footnotetext{
$67 \quad$ Id at pp. 68-69.

68 Id at p. 69 .

69 Ibid.

70 Cobalt-rich regulations, supra note 8 at reg. 11 para. 3(f); Sulphides regulations, supra note 7 at reg. 11 para. 3(f); and Nodules regulations, supra note 6 at reg. 11 para. $3(f)$.

$71 \quad$ Working Draft Regulations and Standard Contract Terms, supra note 13 at p. 4.

72 UNCLOS Art. 139, paragraph 2, and ITLOS, Advisory Opinion of 1 February 2011, supra note 15 at p. 60 .
} 
UNCLOS Annex III, article 22, places liability on the contractor for inflicted damage in the Area for its activities:

The contractor shall have responsibility or liability for any damage arising out of wrongful acts in the conduct of its operations, account being taken of contributory acts or omissions by the Authority. Similarly, the Authority shall have responsibility or liability for any damage arising out of wrongful acts in the exercise of its powers and functions, including violations under article 168, paragraph 2, account being taken of contributory acts or omissions by the contractor. Liability in every case shall be for the actual amount of damage.

The contractor also remains liable for damage after the completion of the exploration phase. ${ }^{73}$ The contractor and the ISA are mainly liable for wrongful acts conducted performing contractor's activities and ISA's powers and fictions respectfully, and not the sponsoring State. ${ }^{74}$ As previously mentioned the sponsoring State is liable for its own failure to carry out its responsibilities, while the contractor is liable for its own non-compliance. ${ }^{75}$

As previously mentioned, the sponsoring State has direct obligations to ensure and adopt appropriate rules and measures, and also enforce these rules and measures at a certain level of vigilance. ${ }^{76}$ One of these direct obligations require the implementation of rules and measures for prompt and adequate compensation or other relief in respect of damage caused by pollution of the marine environment.

\subsubsection{So What Rules and Measures Have Been Implemented by Sponsoring States?}

In 2014, Tonga 'became the first country in the world to put in place a law that manages seabed mineral activities within its national marine space and under its sponsorship in international waters. ${ }^{77}$ Whether this is in fact correct

\footnotetext{
73 Cobalt-rich regulations, supra note 8 at reg. 32; Sulphides regulations, supra note 7 at reg. 32; and Nodules regulations, supra note 6 at reg. 30 .

74 ITLOS, Advisory Opinion of 1 February 2011, supra note 15 at p. 63 .

75 Id at p. 64.

76 Id at p. 42 and Pulp Mills on the River Uruguay case, supra 34 at paragraph 197.

77 Pacific Community - the Geoscience Devision, 'Tonga a world leader in seabed minerals law' (1 September 2014) at http://gsd.spc.int/media-releases/1-latest-news/583 -tonga-a-world-leader-in-seabed-minerals-law.
} 
is debatable. The Seabed Minerals Act $2014^{78}$ established the Tonga Seabed Minerals Authority, regulations of seabed minerals activities within Tonga's national jurisdiction, duties and responsibilities of individuals, prospecting permits and licensing within national jurisdiction, sponsorship of activities in the Area, certain fiscal arrangements, marine scientific research, and some miscellaneous sections. ${ }^{79}$ The Deep Sea Minerals Project, a partnership between the EU, the Secretariat of the Pacific Community and ${ }_{15}$ Pacific Island countries assisted in the preparation of the Seabed Minerals Act. ${ }^{80}$ Chapter 7 of the Act is titled 'Sponsorship of Activities in the Area'; within it section 84 is titled 'Liability of Sponsored Party':

(1) The Sponsored Party shall be responsible for the performance of all Seabed Mineral Activities carried out within the Contract Area, and their compliance with the Rules of the ISA; and will be liable for the actual amount of any compensation or damage or penalties arising out of its failure so to comply, or out of any wrongful acts or omissions and those of its employees, officers, subcontractors, and agents in the conduct of the Seabed Mineral Activities.

(2) Any obligations which are to be observed and performed by the Sponsored Party shall at any time at which the Sponsored Party is more than one person be joint and several obligations.

(3) A Sponsored Party shall at all times keep the Kingdom indemnified against all actions, proceedings, costs, charges, claims and demands which may be made or brought by any third party in relation to its Seabed Mineral Activities.

Other Pacific Island countries, such as Tuvalu, have implemented the same wording the same year. ${ }^{81}$ Nauru made some smaller amendments to

78 The Seabed Minerals Act 2014 (the Kingdom of Tonga), at http://www.eisourcebook.org/ cms/February\%202016/Tonga\%2oSeabed\%2oMinerals\%20Act\%202014.pdf.

79 Ibid.

8o Pacific Community, supra note 77 .

81 Seabed Minerals Act 2014 (Tuvalu), s. 93. 
the same text, ${ }^{82}$ following the wording of Fiji's 2013 enactment. ${ }^{83}$ ISA has also made a list of countries' legislation/reciprocating legislation and national initiatives with respect to the activities in the Area ${ }^{84}$ Singapore's deep sea mining legislation for the Area is less specific:

(1) Where a licensee is responsible or liable for any wrongful act under Annex III, Article 22 of the Convention, the Court may -

(a) order the licensee to pay to a person such compensation for the wrongful act as may be ordered to be paid to that person pursuant to that Article; and

(b) grant to a person such other remedy for the licensee's wrongful act as may be granted to that person pursuant to that Article.

(2) In this section, "licensee" includes a Singapore company which has ceased to hold a licence. ${ }^{85}$

It is apparent from a brief look at some national legislation that sponsored parties are under fault-based liability. One problem with fault-based liability enacted on national level is the more obvious fact that the level of fault that is required to trigger liability will be different between sponsored parties sponsored by different countries, as fault is defined differently among countries. Similarly, rules of evidence various between countries too, which will impact the "hurdle" of attaching fault-based liability to a sponsored party. As these enactments show, some countries have also included an indemnity clause. Taking into account the abovementioned State's responsibility for due diligence, which lack of government oversight contributing to damage attach

82 International Seabed Minerals Act 2015 (Nauru), s. 29: '(1) A Sponsored Party shall be responsible for the performance of all Seabed Mineral Activities carried out within the Contract Area, and their compliance with the Rules of the ISA and shall be liable for the actual amount of any compensation, damage or penalties arising out of its failure so to comply, or out of any wrongful acts or omissions in the conduct of the Seabed Mineral Activities. (2) By operation of this section, Nauru shall be indemnified against all actions, proceedings, costs, charges, claims and demands which may be made or brought by any third party in relation to a Sponsored Party's Seabed Mineral Activities.'

83 International Seabed Mineral Management Decree 2013 (Fiji), s. 33. For more information on Pacific Islands' legislation, see Blue Ocean Law and Pacific Network on Globilization, 'Resource Roulette:How Deep Sea Mining and Inadequate Regulatory Frameworks Imperil the Pacific and its Peoples' (2016) at http://cer.org.za/wp-content/uploads/2016/08/ Resource-Roulette-Deep-sea-Mining-and-Inadequate-Regulatory-Frameworks.pdf, Ch. 5 .

84 ISA, 'Laws, regulations and administrative measures adopted by sponsoring States and other members of the International Seabed Authority with respect to the activities in the Area' (13June 2016), ISBA /22/C/8, at https://www.isa.org.jm/sites/default/files/files/ documents/isba-22c-8_1.pdf.

85 Deep Seabed Mining Act 2015 (Singapore), art. 17. 
liability, and situations where a State is part of a joint venture engaged in deep seabed mining, these indemnity clauses appear unenforceable in certain situations.

\subsubsection{Compensable Damage}

UNCLOS does specify that the amount of damages should be for 'the actual amount of damages'. ${ }^{86}$ This terminology 'actual amount of damages' is repeated word for word in ISA regulation Standard Clauses for exploration contracts $^{87}$ and abovementioned national law regulating activities in the Area. The Tribunal confirmed that the form of reparation depends on actual damages and the technical feasibility of restoring the pollution damage to ex ante, ${ }^{88}$ relying on article 34 of the ILC Articles on State Responsibility when determining the form of reparation, which states:

Full reparation for the injury caused by the internationally wrongful act shall take the form of restitution, compensation and satisfaction, either singly or in combination, in accordance with the provisions of this chapter. ${ }^{89}$

Neither UNCLOS nor the Regulations define or specify compensable damage, or which subjects are entitled to damages. ${ }^{90}$ However, the Tribunal lists a couple of possible types of damage: damage to the Area, damage to the Area's resources considered the common heritage of mankind, and damage to the marine environment. ${ }^{91}$ The lack of further clarity on what damage categories are compensable and how to actually calculate this 'actual amount of damages', place a large responsibility on the sponsoring States and national legislation to properly do this. It also opens up for forum shopping by contractors when choosing from with jurisdiction to conduct activities in the Area. A sense of such bias by the contractor could presumably initiate sponsoring States facilitating for more lenient national liability and compensation legislation as well

\footnotetext{
86 UNCLOS Annex III, art. 22.

87 Cobalt-rich regulations, supra note 8 at reg. 32 in conjunction with Annex IV section 16.1; Sulphides regulations, supra note 7 at reg. 32 in conjunction with Annex 4, section 16.1; and Nodules regulations, supra note 6 at reg. 30 in conjunction with Annex IV section 16.1.

88 Id at p. 63 .

89 International Law Commission 'Responsibility of States for Internationally Wrongful Acts' (2001) II Yearbook of the International Law Commission, Part Two, art. 34.

9o Cobalt-rich regulations, supra note 8 at reg. 32; Sulphides regulations, supra note 7 at reg. 32; and Nodules regulations, supra note 6 at reg. 30 .

$91 \quad$ ITLOS, Advisory Opinion of 1 February 2011, supra note 15 at p. 59.
} 
as environmental legislation to attract the financial benefits of sponsoring a contractor. Damage Caused in the Area

\subsection{The Lack of a Proper Liability and Compensation Scheme for Deep Seabed Mining}

ISA, entities engaged in deep seabed mining, other users of the sea, and Coastal States are some examples the Tribunal explicitly states as subjects that may claim compensation for pollution damage in the Area. ${ }^{92}$ Claims against the contractor (sponsored party) may either be paid or not paid. If the contractor has paid the actual amount of damages, 'there is no room for reparation by the sponsoring State. 93 This presumes that the concept of 'actual amount of damages' corresponds with compensation in full, which should be full environmental restitution. This is hardly the case.

In certain situations, such as blameless actions of the contractor or simply contractor's bankruptcy, the contractor may end up not paying for pollution damage in the Area. As stated above, strict liability is not the standard of liability applicable to the sponsoring State. There is also no residual liability for the sponsoring State, ${ }^{94}$ and the sponsoring State and the contractor does not bear joint and several liability, which is a standard applicable where different entities have contributed to the same damage so that compensation in full can be achieved. ${ }^{95}$ As a result, certain liability gaps' may occur in situations where the contractor does not pay the actual amount of damage. The fault-based limitation on liability for sponsoring States leaves at least three liability gaps:

- where a state takes all necessary and/or appropriate measures required by international law and the blameless actions of the contractor nevertheless cause environmental harm;

- where a state takes the requisite necessary and/or appropriate measures and the private operator is blameworthy, but insolvent or its assets are beyond the reach of the sponsoring state; and

- where the sponsoring state has failed to take the required measures but there is no causal link with the environmental harm. ${ }^{96}$

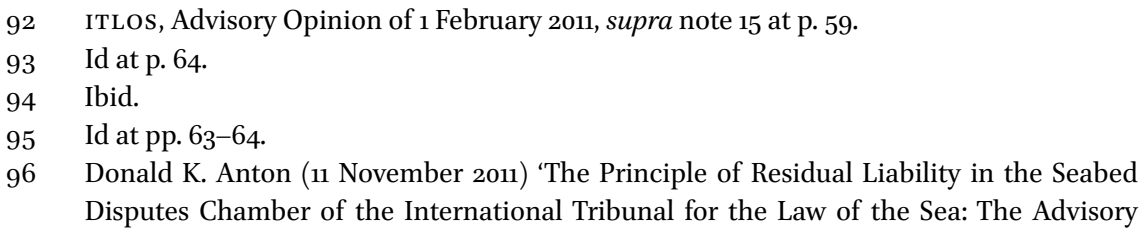


These liability gaps are currently not protected under international law, and compensable. Article 304 of UNCLOS allows further developments of international law to be implemented into the deep seabed liability regime, and also further developments of the deep seabed liability regime specifically. ${ }^{97}$

\section{2}

\section{An Alternative Model of Liability and Compensation}

3.2 .1

Sponsored Contractor's Strict Liability for Pollution Damage in the Area

IT LOS states that the sponsoring States may apply more stringent standards as far as the protection of the marine environment is concerned to their contractors. ${ }^{98}$ Sponsoring States should implement strict liability for their contractors for pollution damage from activities in the Area, as such activities are hazardous, to ensure prompt and adequate compensation. ${ }^{99}$ There is no good reason why injured parties and the environment should take the risk of contractors adhering to a negligence standard for pollution damage in the Area. The cost of such liability can be internalised and offset to some extent by insurance. ${ }^{100}$ The Norwegian Petroleum Act ${ }^{101}$ is a good example of how strict liability on the licensee for pollution damage caused by petroleum does not limit the interest from national and international companies to explore and produce oil and gas on the Norwegian Continental Shelf.

\subsubsection{Pollution Damage Fund under the ISA}

ITLOS suggested that ISA should consider the option of setting up a damage fund as a means to cover damages that are not otherwise covered by the deep seabed mining liability scheme, the liability gap. ${ }^{102} \mathrm{~A}$ pollution damage fund would be a good way of creating a second layer of safety to ensure compensation of pollution damage in the Area, for situations where the sponsored contractor become delinquent and claims are beyond the scope of its insurance. ${ }^{103}$ Such

Opinion on Responsibility and Liability for International Seabed Mining (ITLOs Case No. 17)' McGill International Journal of Sustainable Development Law and Policy, at https:// ssrn.com/abstract=1957907, pp. 12-13 referring to Written Statement of the International Union for the Conservation of Nature, at http://www.itlos.org/fileadmin/itlos/docu ments/cases/case_no_17/StatementIUCN.pdf, pp. 28-29.

97 ITLOS, Advisory Opinion of 1 February 2011, supra note 15 at p. 66.

98 Id at p. 73 .

99 ILC, 'Draft principles on the allocation of loss in the case of transboundary harm arising out of hazardous activities' (2006) International Law Commission, 58th session, art. 4(2).

100 Working Draft Regulations and Standard Contract Terms, supra note 13 at sec. 8.

101 Lov om petroleumsvirksomhet $1996 \mathrm{nr} .72$.

102 ITLOS, Advisory Opinion of 1 February 2011, supra note 15 at pp. 65-66.

103 ILC, 'Draft principles on the allocation of loss in the case of transboundary harm arising out of hazardous activities' (2006) International Law Commission, 58th session, art. 4(4). 
a fund should be under the ISA, as the international regulatory body and collector of certain deep seabed related fees. ISA has created draft regulation to establish a Environmental Liability Trust Fund. ${ }^{104}$

\subsubsection{Residual Liability for the Sponsoring State}

The sponsoring State is not residually liable for a contractor's non-compliance. ${ }^{105}$ However, sponsoring States should be liable in last instance as deep seabed mining is a significant hazardous activity. ${ }^{106}$ The sponsoring States set the financial requirements of the contractor and can increase financial security requirements of the contractor to decrease its own risk. The environment in the Area, the common heritage of human kind, should not be put at risk and suffer when this could be avoided.

\section{$4 \quad$ Conclusion}

The sponsoring State's liability arises from its own failure to carry out its responsibilities, whereas the sponsored contractor's liability arises from its own non-compliance. These two forms of liability exist simultaneously and in parallel. The only connection between the two is that the sponsoring State's liability depends upon the sponsored contractor's damage resulting from activities or omissions. ${ }^{107}$ This system facilitates for liability gaps, which could and should be removed by enacting on a national level strict liability for pollution damage in the Area on the sponsored contractor, an international seabed pollution damage fund, and residual liability on sponsoring States. This is stricter than the current international legal situation, but international law is constantly evolving and should evolve accordingly.

\footnotetext{
104 ISA, 'Developing a Regulatory Framework for Mineral Exploitation in the Area: a Discussion Paper on the development and drafting of Regulations on Exploitation for Mineral Resources in the Area (Environmental Matters)' (January 2017) at https://www .isa.org.jm/files/documents/EN/Regs/DraftExpl/DP-EnvRegsDraft25117.pdf, pp. 72-74.

105 Position put before ITLos by amongst others R.A. Makgill et al., Written Statement of International Union for Conservation of Nature and Natural Resources, Commission on Environmental Law, Oceans, Coastal and Coral Reefs Special Group (19 August 2010) at https://www.itlos.org/fileadmin/itlos/documents/cases/case_no_17/StatementIUCN.pdf, pp. 29-32.

106 ILC, 'Draft principles on the allocation of loss in the case of transboundary harm arising out of hazardous activities' (2006) International Law Commission, 58th session, art. 4(5).

107 ITLOS, Advisory Opinion of 1 February 2011, supra note 15 at p. 64.
} 